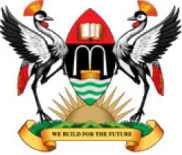

East African School of

Higher Education Studies \& Development
Makerere Journal of Higher Education

ISSN: $1816-6822 ; 3(1)(2011) 91-100$

DOI: http://dx.doi.org/10.4314/majohe.v3i1.8

(C) The Author(s) 2011

Reprints \& permission: EASHESD

http://ajol.info/majohe

\title{
Awareness, Availability and Utilization of Research Findings in Building the Education Sector for Sustainable Development
}

\author{
Chinelo O. Duze ${ }^{1}$ \\ ${ }^{1}$ Delta State University [E-mail: chineloduze@yahoo.com]
}

\begin{abstract}
This study examined the extent of awareness, availability and utilization of educational research findings in enhancing the effectiveness of educational practices for sustainable development. A structured questionnairecompleted by a sample of 726 respondents, including lecturers, government officials and higher education students - sought perceptions on these variables in Nigeria. The data collected were analyzed using percentages, means and ANOVA. The results revealed no significant differences on awareness about and availability and utilization of research findings. However, availability of research findings was scored poorest by the three categories of respondents. Respondents that were involved in conducting research were most aware of research findings $(81 \%)$. Nevertheless, a much smaller percentage $(28 \%)$ of them indicated that they used these research findings in addressing professional and development challenges. Recommendations towards increased utilization of research findings are made.
\end{abstract}

Keywords: Evidence based policy; Research utilization; ESD

\section{$1 \quad$ Introduction}

This study is concerned with the "re-engineering" of educational research and outcomes for sustainable national development in Africa. Specifically, the study examined the extent of awareness, availability and utilization of educational research findings in solving education's problems and enhancing educational practices for rapid economic growth and sustainable national development.

Education and its benefits to any country's development are enormous and appreciated even by those who never saw the four walls of the school. But for education to work its optimum for us, we must make maximum use of all that it 
offers. What education can do for a man and his society and by furtherance, what education can do for any nation if her citizens were well educated, is vividly presented in Ojo (2003) study as follows:

1. The educated man sees himself as a useful member of every society and as one who has a sacred duty to protect, sustain and serve that society.

2. The real educated man is the one who will do nothing to undermine the integrity of his society and will never engage in anything that will negate or destroy what the society holds dear - society's common properties, its resources and its soul. Indeed, he has an unselfish devotion to public interests and uncommon commitment to the sustenance of society's valuesystems.

3. He demonstrates an informed and intelligent understanding of public affairs.

4. Education is anti-ignorance and anti-mediocrity. Education builds up the mind, gives and increases knowledge, widens horizon, helps the learner to acquire new skills which also brings out the best of the individual, and in the end, the society.

5. Education refines the individual, enlightens him and makes him cultured and cultivated.

6. Education is anti-conformism because it opens up new vistas, new terrains and options from which choices are constructively made and which makes progress and development possible.

7. Education emboldens, empowers and helps the individual to make rational and informed decisions, to take principled stand on issues, and to conduct himself decently, rationally, and fully conscious of the implications of each of his actions and options.

8. Education is an instrument of change. The objective of change is to transform man from his original, natural, and crude state, through guided instruction, gradual orientation and knowledge to become an individual who is refined and civilized.

9. Education is a sure companion, a viable partner, a dependable friend, a trustworthy ally, an omnibus helper, handy at all times, and helping to make the individual a respected member of his society.

10. Education gives confidence to the individual and helps to raise his head at all times, and this, without pomposity and bridge but with humility and decorum.

11. Each of the education members is fully conscious of his rights and those of other members of the society. Each one tries to defend such rights very jealously and also endeavours not to trample on the rights of the others.

From this, we can conveniently declare that education makes the individual useful to himself and to his society. It enables the individual discover himself better and be better positioned to respond to the needs of the people living in 
his community. This in turn enables the society to be receptive and to progress, and to want to invest the more on the individual so as to allow him to profitably and positively explore his weaknesses, strengths, and potentials to make him happy, fulfilled and endowed with a sense of belonging. This type of educated person can only emanate from the education factories of higher institutions. This investment can only be effectively done through research, and, it is the higher institutions that must carry out researches for the betterment of the individual, the society, the nation, and the entire universe. These efforts will certainly be fruitless and would amount to investment in frustration when the findings from research are not properly disseminated and appropriated. Therefore, the outputs of research ought to be made known to the general public, be reachable when needed, and should be used by all concerned in solving human problems.

Furthermore, investments in education seem to have failed to deliver the goods in African countries, since most African countries are still battling with under-development, in the sense that the following indices of development noted by Udoidem (1992) are still eluding most African nations:

1. A reduction of the level of unemployment;

2. A reduction of the extent of personal and regional inequality;

3. A reduction of the level of absolute poverty;

4. A rise in the real output of goods and services and the improvement of the techniques of production;

5. Improvement in literacy, health services, housing conditions, and government services;

6. Improvement of the social and political consciousness of the people; and

7. Greater ability to draw on local resources (human and material) to meet the local needs, that is, becoming self reliant.

Talking about "re-engineering" implies that there is a discrepancy in the handling of education and development that must be addressed to ensure education's capacity to bring about sustainable national development. To "reengineer" effectively, research findings must be disseminated and appropriated. It appears we have not fully understood in Africa what research can do in the education sector in enhancing sustainable national development. That research is a fundamental tool for knowledge development and dissemination, the essence of which is to logically and systematically find solutions to human problems for better living is not in doubt. Industrialized countries have continued to use research for greater development. Besides, there is no aspect of the benefits of education or the indices of development that cannot be studied and evaluated empirically. Research findings in education abound to the extent that we have no reason in Nigeria or Africa for that matter, to be retrogressing in development and modernization. What may be a problem could be in the area of awareness, availability, and utilization. 
Research in education has increasingly recorded a significant correlation between literacy and sustainable development, yet as many as $44 \%$ of Nigeria's adult population compared to Indonesia's 32\%, China's 27\%, Egypt's 26\%, Brazil's 19\%, and Mexico's $13 \%$ are unable to read and write in any language (Okoli and Duze, 2009). Among African Countries, Nigeria was noted to have allocated the least in recent years to education (highest $11.12 \%$ in 1999 , lowest $1.83 \%$ in 2003) as against UNESCO's $26 \%$ minimum budgetary allocation to education (ASUU, 2002) whereas Egypt, Gambia, Gabon, Mauritius and Libya are doing well relatively in funding education (Ajao, 2003). This portrays a measure of irresponsibility on the part of policy makers in government. Nigeria, as wealthy as she is, occupying the position of the $6^{\text {th }}$ largest producer of oil in the world, is ranked $151^{\text {st }}$ out of 174 countries on the recent HDR rating. This ranking implies a situation of absolute poverty. School enrolment, access to good education, access to water and power, proper health services, infant mortality, fertility rates, nutrition rates, life expectancy, food deficit position, etc are all posing great threats and painting a vivid picture of a nation in distress (Anya, 2003). This scenario is disquieting and worrisome, as the situation continues to take a downward plunge into what may be described as a national disaster. The question is: could the extent of awareness, availability, and utilization of educational research findings explain the missing link between education and sustainable development in Nigeria?

Research is a complex activity and its contribution to nation-building is enormous. This has necessitated the continuous call by governments, research organizations, universities, and other higher institutions for a vibrant research function in higher education worldwide. To achieve this, special attention must be paid to its management, important among which, are proper dissemination and appropriation of research findings. The management of research involves all the activities and processes directed at creating an enabling environment for it to flourish as well as ascertaining good practices and quality output. These will obviously include the policies to be made, the planning for the present and future, the provision of human and physical resources such as staff, funding, and equipment and materials. To this extent, the practices, the challenges, and the opportunities for reform and sustainable development will differ in different continents and countries of the world. It has been observed that even in industrialized settings where enviable grounds have been gained in research and development due to their appreciable support systems, there still exist some forms of challenges in the research function. In Africa, proper management is lacking hence the research function has continued to attract significant criticisms worldwide. While African scholars outside the continent are making significant inputs into global knowledge in science and technology through research, those inside Africa seem to be handicapped. Though there have been achievements and good practices in higher education research, the impediments 
in research publication, recessions in opportunities, and bad practices tend to overshadow the former. However, the multiple challenges we are experiencing in our developing continent should not dampen our efforts, but rather ginger us into digging deeper, wider, and longer into known and unknown information to overcome these challenges. This would involve awareness, availability, and utilization of such information. Though the consensus on the need for research in higher education is compelling, what we need most importantly in doing so, is to obtain reliable and quality information about our peculiar circumstances in different African countries, to enable us strengthen our research function, appreciate the criticisms, and make future improvements in our practices and opportunities for sustainable development. It is from the foregoing that this paper x-rayed the extent of awareness, availability, and utilization of research findings in building the education sector in Nigeria for sustainable national development, and to proffer the next steps forward. To guide the trust of this study, four research questions were raised from which three null hypotheses were formulated.

\subsection{Research Questions}

1. What is the extent of awareness, availability, and utilization of research findings by lecturers, students, and government policy-makers in Nigeria?

2. Is there any difference in the extent of awareness of the usefulness of research findings by higher institution lecturers, students, and government policy-makers in building the education sector for sustainable national development?

3. Is there any difference in the extent of availability of research findings to these three categories of stakeholders in Nigeria?

4. Is there any difference in the extent of utilization of research findings by these three categories of stakeholders in Nigeria?

\subsection{Research Hypotheses}

Ho$_{1}$ : There is no significant difference in the mean responses of lecturers, students and policy-makers on the extent of awareness of the usefulness of research findings in building the education sector for sustainable national development.

$\mathbf{H o}_{2}$ : There is no significant difference in the mean responses of lecturers, students, and policy-makers on the extent of availability of research findings in Nigeria.

Ho $_{3}$ : There is no significant difference in the mean responses of lecturers, students, and policy-makers on the extent of utilization of research findings in Nigeria. 


\section{$2 \quad$ Methodology}

The study is a survey which examined the extent of awareness, availability, and utilization of research findings in solving education's problems and enhancing educational practices for sustainable national development by three categories of stakeholders in Nigeria - lecturers, students, and government policy-makers which represent the target population. A sample of 726 subjects selected through stratified random sampling, comprising 196 lecturers, 481 students, and 49 policy-makers, was used for the study. The instrument used to collect data for the study was a structured questionnaire containing 36 items on a four-point scale of Very High (4 points), High (3 points), Low (2 points), and Very Low (1 point), which elicited considerable information on each of the three variables of study - awareness, availability, and utilization of research findings in building the education sector for sustainable development. The validity of the instrument was certified by research experts in education. In a pilot test administered to a total of thirty respondents not involved in this study (the three categories well represented), a reliability coefficient of 0.84 was obtained for the instrument through the Split-half method also duly stepped up by the Spearman Brown Formula. The questionnaire copies were administered and retrieved by the researcher with the help of research assistants with all duly completed. These were analyzed using the simple percentage, mean, and ANOVA.

\section{$3 \quad$ Results}

Data were analyzed according to how they related to the one research question answered and the three null hypotheses tested in the study and results presented in Tables 1-4. To test the three null hypotheses formulated, the responses of lecturers, students and government policy-makers were isolated and scored for each of the variables, and their respective mean scores computed. The three independent mean scores were subjected to the One-way analysis of Variance (ANOVA) for each of the three variables investigated and tested at the 0.05 level of significance, $\mathrm{df}=2,723$, and region of rejection $\mathrm{R}: \mathrm{F}>3.00$ (Tables 1, $2,3$ and 4$)$.

Table1. Awareness, Availability and Utilization of Research Findings in Education

\begin{tabular}{lllllll}
\hline Variables & \multicolumn{2}{l}{ Lecturers $\mathrm{n}=\mathbf{1 9 6}$} & \multicolumn{2}{l}{ Students $\mathrm{n}=\mathbf{4 8 1}$} & \multicolumn{2}{l}{ Government Policy-makers $\mathrm{n}=\mathbf{4 9}$} \\
& $\mathrm{f}$ & $\%$ & $\mathrm{f}$ & $\%$ & $\mathrm{~F}$ & $\%$ \\
\hline Awareness & 177 & 89.85 & 382 & 79.42 & 40 & 81.63 \\
Availability & 68 & 34.69 & 149 & 30.98 & 13 & 26.53 \\
Utilization & 72 & 36.74 & 161 & 33.47 & 14 & 28.57 \\
\hline
\end{tabular}


The result in Table 1 showed that $89.85 \%$ of lecturers, $79.42 \%$ of students, and $81.63 \%$ of government policy-makers sampled were aware of the importance of research findings in building the education sector for sustainable development, but all the categories recorded below fifty percent in availability and utilization, with availability lagging behind. Government policy-makers recorded the lowest percentages of $26.53 \%$ and $28.57 \%$ in availability and utilization respectively, followed by the students $(30.98 \%$ and $33.47 \%)$, and the lecturers $(34.69 \%$ and $36.74 \%)$.

Table 2: ANOVA for Awareness of Usefulness of Research Findings

\begin{tabular}{lllllll}
\hline Source of Variation & df & SS & MS & $\mathbf{F}_{\text {cal }}$ & $\mathbf{F}_{\text {critical }}$ & Decision \\
\hline Between Groups & 2 & 37.06 & 18.53 & & & Not significant \\
Within Groups & 723 & 9165 & 12.66 & 1.46 & 3.00 & \\
Total & 725 & 9202.06 & - & & & \\
\hline
\end{tabular}

The result in Table 2 showed that the calculated $\mathrm{F}$ value of 1.46 is numerically smaller than the critical $\mathrm{F}$ value of 3 therefore the null hypothesis was retained. This means that there was no significant difference between the three groups of respondents implying that students, lecturers and government policy-makers were well aware of the usefulness of research outputs in building the education sector for sustainable development.

Table 3: ANOVA in Availability of Research Findings

\begin{tabular}{lllllll}
\hline Source of Variation & $\mathbf{d f}$ & SS & MS & $\mathbf{F}_{\text {cal }}$ & $\mathbf{F}_{\text {critical }}$ & Decision \\
\hline Between Groups & 2 & 35.39 & 17.70 & & & Not significant \\
Within Groups & 723 & 11062.72 & 15.28 & 1.16 & 3.00 & \\
Total & 725 & 10820.98 & - & & & \\
\hline
\end{tabular}

The result in Table 3 showed no significant difference between the three groups of respondents because the calculated $\mathrm{F}$ value of 1.16 was numerically smaller than the critical $\mathrm{F}$ value of 3.00, and therefore, the null hypothesis was retained. This implied that the extent of research findings availability to students, lecturers, and government policy-makers was more or less the same.

Table 4: ANOVA in Utilization of Research Findings

\begin{tabular}{lllllll}
\hline Source of Variation & Df & SS & MS & Fcal & Fcritical & Decision \\
\hline Between Groups & 2 & 20.33 & 10.17 & & & Not significant \\
Within Groups & 723 & 6487.04 & 8.96 & 1.14 & 3.00 & \\
Total & 725 & 6507.37 & - & & & \\
\hline
\end{tabular}

The result in Table 4 showed that the calculated $\mathrm{F}$ value of 1.14 is numerically smaller than the critical $\mathrm{F}$ value of 3 therefore the null hypothesis was retained 
meaning that there was no significant difference between the three groups of respondents in the extent of research findings utilization in Nigeria.

\section{Discussion, Conclusion and Recommendations}

The only research question empirically answered and the three null hypotheses tested in this study all point to the fact that the stakeholders in higher education studied - lecturers, students, and government policy-makers, were all well aware of the enormous contributions that research outputs can make in solving education's problems and enhancing educational practices for sustainable national development, but have indicated low levels in research output availability and utilization, with availability lagging behind. Despite the discovery that policy-makers who are the producers of education recorded a handsome score of 81.63 percent in awareness, they hardly ever bothered to search for and adopt research outputs in planning and managing education, as evidenced in their poor scores of 26.53 percent in availability and 28.57 percent in utilization.

This may amount to indifference to issues that must actually be addressed in order to raise the living standards of the majority of Nigerians living in abject poverty by government. This has been the problem in Nigeria and most African countries where educational policies have been highly politicized to suit the government in power rather than address the real needs of the education sector. Even when astute academics who have published ideal research findings in international journals for boosting the education sector were appointed into political positions, they tended to fall back to "politics-and-power" forgetting their books! This observation was also made by Oghenekohwo et al (2007) on "University carrying capacity and incidence of higher education efficiency in Nigeria" whose chief recommendation was that higher education should be depoliticized. Furthermore, this record underpinned the fact that policy-makers are not truly committed to solving education's problems since they know what to do but fail to do it. For instance, research findings have repeatedly pointed to lack of adequate funding as responsible for the myriads of problems in education yet, the Nigerian government continues to increasingly reduce budgetary allocations to education and starve educational institutions of necessary funds (Ajao, 2003; ASUU, 2002; Okebukola, 1998; Okon, 2006). In the same vein, the extent of awareness of lecturers $(89.85 \%)$, the ones who conduct most of the researches, is higher than for availability (34.69\%) and utilization $(36.74 \%)$.

This could be due to the inability to access the internet for information, institutions' poor and obsolete libraries, and financial constraints in publishing 
research studies in books and journals for wider usage. However, they seem to use whatever is available only to satisfy the conditions for promotion to the next rank in order to beat the "Publish-or-Perish" syndrome of academics in Nigeria. The same applied to students who are the direct consumers of education, indicating 79.42 percent in awareness, 30.98 percent in availability, and 33.47 percent in utilization. They seem to find and use research outputs only available in their own institutions, and only for the purpose of making inputs into their own research projects which are compulsory requirements in higher institutions for graduation in Nigeria. It is commonly observed that volumes of valuable research reports done by academics and students which addressed the problems of Nigeria and other African nations are stacked away in departmental and faculty offices, gathering dust and occupying scarce spaces rather than being widely disseminated and appropriated in solving human problems and thus lifting African nations from extreme poverty to economic growth and modernization. So, for government policy-makers who have nothing personal at stake, they simply sit in their glamorous air-conditioned offices powered by gigantic noiseless generators and drink tea or coffee to keep warm, and read newspapers!

These findings reflect Okebukola's (2002) and Adu's (2003) findings on research and publication in Nigeria. Okebukola (2002) noted that the highest number of publications by Nigerian academics in international journals between 1962 and 2000 was ten in 1998 which dropped to only one in 2000. Also the highest number of active local journals was twenty-two in 1998 and had dropped to three in 2000. Adu (2003) had lamented Nigeria's lowest volume of research and publication (711) in 1995 as compared to some other third world countries (South Africa, 3,414; Brazil, 5,440; and India, 14,883), despite having the largest number of universities (86) in Sub-Saharan Africa.

Results and findings have shown that there is poor dissemination (availability) and appropriation (utilization) of research findings in Nigeria despite great awareness of their usefulness in solving education's problems and enhancing the quality of life of the citizens. It therefore means that research outputs from higher education in Nigeria have not been able to translate into development indices appreciably, and consequently, have not helped in building the education sector effectively for sustainable national development.

From this discourse, and hoping that Nigeria would one day find reason to adopt research findings appreciably in solving the myriads of problems of education and underdevelopment, and thereby begin to reap the fruits of the well-educated citizens as enumerated by Ojo (2003) and enjoy the indices of development listed by Udoidem (1992), as discussed in the introduction of this paper, we join other researchers to continue to echo the need to de-politicize education as well as adequately fund it to attain sustainable national development. Furthermore, research findings should be made known to the 
general public, should be made available for use in solving the human problems that militate against sustainable national development. We could begin by opening avenues for research dissemination like "research-bank" akin to a blood-bank and the like.

\section{References}

Adu, F. I. (2003) Challenges of university management in contemporary Nigeria. Acceptance speech at the vice-chancellor of the year 2002 award ceremony at Abuja, Nigeria.

Ajao, W. (2003) UN literacy decade 2003-2012: Will Africa succeed? Vanguard, Dec. 11, p.23.

Anya, A. O. (2003) "Leadership, education, and the challenge of development in the $21^{\text {st }}$ century. Vanguard, October 21, p. 26.

ASUU Bulletin. (2002) A publication of Academic Staff Union of Universities, Nigeria.

Oghenekohwo, J. E.; Adekola, G., Olufunmilayo, T. I. (2007) University carrying capacity and incidence of higher education efficiency in Nigeria. African Journal of Education and Developmental Studies, 4 (1): 127-142.

Ojo, S. A. (2003). Education in a democracy: the Nigerian Case. Vanguard, May 8, pp. 27 \& 30.

Okebukola, P. (1998). Trends in tertiary education in Nigeria. In UNESCO (ed.) The State of Education in Nigeria. Lagos: UNESCO Lagos Office.

Okebukola, P. (2002) Refocusing education in the context of research publication trends. In Oriaifo, S. O. (ed.) Refocusing Education in Nigeria. Benin-City: Da-Sylva Influence.

Okoli, C. S., Duze, C.O. (2009). Education in Nigeria from 1842 to present day. Unpublished Seminar Paper, Delta State University, Abraka.

Okon, J. E. (2006). Historical development of educational administration. In J. B. Babalola; A. O. Ayeni; S. O. Adedeji; A. A. Suleiman; M. O. Arikewuyo (Eds.) Educational Management: Thoughts and Practice. Ibadan: Codat Publications.

Udoidem, S. I. (1992). Values and National Development. Lagos: Heritage Research and Publications. 